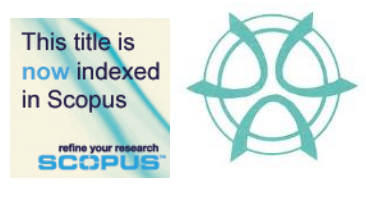

PLANNING MALAYSIA:

Journal of the Malaysian Institute of Planners

Volume XI (2013), Page 97 - 124

\title{
COMMUTERS' PERCEPTIONS ON RAIL BASED PUBLIC TRANSPORT SERVICES: A CASE STUDY OF KTM KOMUTER IN KUALA LUMPUR CITY, MALAYSIA
}

\author{
Syahriah Bachok ${ }^{1}$, Mariana Mohamed Osman ${ }^{2}$, Ummi Aqilah Khalid $^{3} \&$ \\ Mansor Ibrahim ${ }^{4}$ \\ ${ }^{1,2,3 \& 4}$ Kuliyyah of Architecture and Environmental Design \\ INTERNATIONAL ISLAMIC UNIVERSITY MALAYSIA
}

\begin{abstract}
In facing the challenges of urban traffic congestion, when people are becoming more dependent on private vehicles, public transportation services should be functioning effectively as attractive alternative modes. This research evaluates how rail public transport users perceive day to day quality of the provided services. The study investigates commuters' satisfaction levels of various trip making aspects on board KTM Komuter trains, a commuter services operated by the company Keretapi Tanah Melayu Berhad (KTMB), a heavy rail operator in Kuala Lumpur, Malaysia. A systematic probabilistic sampling questionnaire survey was conducted among the users during the month of December 2011 until March 2012. A sample of 1000 questionnaire forms returned by respondents have been gathered for purposes of ascertaining the overall satisfaction level and analysis on selected aspects of the performance indicators. The results have shown that the majority of the respondents perceived KTM Komuter services to be below the levels that the users had expected, especially the non-adherence to published schedule and travel times, frequency or headways, capacity, the physical conditions of the rail coaches and the information on delays. Most of them expected better services to increase their satisfaction levels. Hence, it is concluded that for the rail public transportation to be sustainable and continuously relevant, the operator has to increase KTM Komuter's effectiveness and efficiency or the services have to in the least remain attractive to the existing users
\end{abstract}

${ }^{1}$ Assistant Professor at Department of Urban and Regional Planning. Email: syahriah@iium.edu.my 
Syahriah Bachok, Mariana Mohamed Osman, Ummi Aqilah Khalid \& Mansor Ibrahim

Commuters' Perceptions on Rail based Public Transport Services: A Case Study of KTM Komuter in Kuala

Lumpur City, Malaysia

Keywords: public transportation, commuter rail, KTM Komuter, Kuala Lumpur, users' perception.

\section{INTRODUCTION}

Urban dwellers in developing countries require and demand mobility and accessibility in the same rates at the growth of these urban areas. Often, this demand is accommodated by the increase number of private vehicles. However, meeting the demand through private vehicles is unsustainable for various arguments. Environmental issues are always associated with transportation, with the major contributor being the private vehicles, found travelling on many of the developing cities' roads including Kuala Lumpur, Malaysia. As the capital city of Malaysia, Kuala Lumpur continues to be flooded with newly registered motor vehicles each year. With the increase in the country's overall personal and disposable income levels, the increase in demand for private vehicle ownership is inevitable. According to the Road Transport Department of Malaysia (2011), Kuala Lumpur's percentage share of the newly registered motor vehicles has increased from 115,661 vehicles in 2000 to 208,560 in 2010 with an annual average growth rate of 4.45 per cent.

An increase in vehicle ownership and registered vehicles, while increasing mobility and accessibility, resulted in high urban traffic congestion, increase travel time, high demand for parking spaces in city centres and high rates of injury and fatality which all lead to environmental degradation. Hence, many public transport advocators in developing cities would argue for the switch from private vehicles to public transportation, to ameliorate these negative effects of transportation.

However, in developing countries too, these two aspects are declining rapidly together with the services of public transport system. More and more housing are constructed further and further away from the city centres as land prices increase, resulting in more expensive journey making and lack of choices of travel modes. It is also argued that the service qualities of public transport in the majority of developing countries are deteriorating due to overloaded capacity and the lack of maintenance (Senbil, et al., 2005; Bachok, 2010).

Public transportation are shared or collective vehicles often operated with designated routes and fixed scheduled. Public transport system is a complex systems consisting of various sub-systems including various road, rail, 
water and air systems, vehicles or rail coaches system, track and signalling system, route and scheduling system, fare and ticketing system, interchange and transfer system and integrated information system.

Demand for public transport is often mixed and diverse, by both captive and choice riders. Public transport faces challenges from various corners, including competition from private vehicles, dwindling patronage, generation of lower revenue to sustain its operation and decreasing financial support from the public sector, which in turn, further exacerbated the poor performance of public transport and decreased the attractiveness of public transport among private transport users. Many private vehicles users' perceived public transportation as an inferior service compared to the more comfortable and convenient private vehicles. Subsequent to these issues, the Malaysian government has formulated the Government Transformation Programmes (GTPs) in 2011, chief amongst which have been targeted especially on the improvement of urban public transport to tackle the public transportation issues, to increase the streamline capacity, to introduce an integrated ticketing platform and fare structure and to develop an Integrated Transport Terminals (ITTs) outside the city centre areas (Malaysian Government, 2011). The idea is to achieve 25 per cent modal share by the year 2015 by enhancing public transport performance in terms of reliability, travel time, comfort, accessibility and connectivity (Malaysian Government, 2011). Consequently, these initiatives would reduce the impacts of transportation on the environment and thus ensuring sustainability.

This paper discusses some of the issues concerning one particular public transport system, namely KTM Komuter services delivery. KTM Komuter service is one of the three rail services operated by Keretapi Tanah Melayu Berhad (KTMB), a public limited company overseeing and managing the heavy-rail systems in Kuala Lumpur, Malaysia. There exist four other rail systems namely light rail systems of Ampang line and Kelana Jaya line, monorail system, KLIA Express and KLIA Transit systems. Soon, by 2018, an additional system of mass rapid transit (MRT) system will also be operating to accommodate the demand of over 5 million urban dwellers of Kuala Lumpur region. The interest in evaluating the services performance of KTM Komuter, has been raised from the issues and problems identified by the literature and previous research's analyses that highlighted the needs for more efficient and reliable KTM Komuter services, as one of the many approaches of achieving a more sustainable transportation system in Malaysia (Bachok, 2010). 
Syahriah Bachok, Mariana Mohamed Osman, Ummi Aqilah Khalid \& Mansor Ibrahim

Commuters' Perceptions on Rail based Public Transport Services: A Case Study of KTM Komuter in Kuala

Lumpur City, Malaysia

\section{Study objectives}

The study revolves around achieving the following objectives:

i. To examine the users' perception of the service quality provided by KTM Komuter

ii. To identify improvement elements to increase the level of services of KTM Komuter

\section{PUBLIC TRANSPORTATION IN KUALA LUMPUR}

There exist two main types of public transportation in Kuala Lumpur namely road- and rail-based public transportation. This research sets its realm to only elaborate on the services provided by KTM Komuter, a rail commuter service provided alongside four other rail systems.

\section{KTM Komuter}

KTM Komuter is a commuter train service operating in Kuala Lumpur region of Malaysia, operated by Keretapi Tanah Melayu Berhad (KTMB). KTMB also operates two other services namely intercity passenger and freight services. KTM Komuter is currently the most profitable passenger service offered, contributing to RM84.63 million to group revenue in 2006, higher than KTM InterCity's profit of RM70.94 million in the same year (KTM Komuter management, personal communication, 2012). It was introduced in 1995 to provide local rail services in Kuala Lumpur and the surrounding Klang Valley suburban areas. According to the Ministry of Transport, Malaysia's statistics (2010), the ridership of KTM Komuter was approximately 36.557 million passengers per annum, which translated to nearly 100,000 passengers daily.

KTM Komuter is a heavy-rail public transport service moving commuters from the suburban localities of Kuala Lumpur region to the city centre. It has been one of the major transport providers in the city and has great potential to be an alternative sustainable transport mode to the traffic on congested road networks. This mode of transportation also provides access and mobility to those who do not have access to a private vehicle. However, KTM Komuter has during the last few years been stigmatized by various issues and problems including, overcrowding, congested and excessive and persistent delays (Bachok, 2010). 


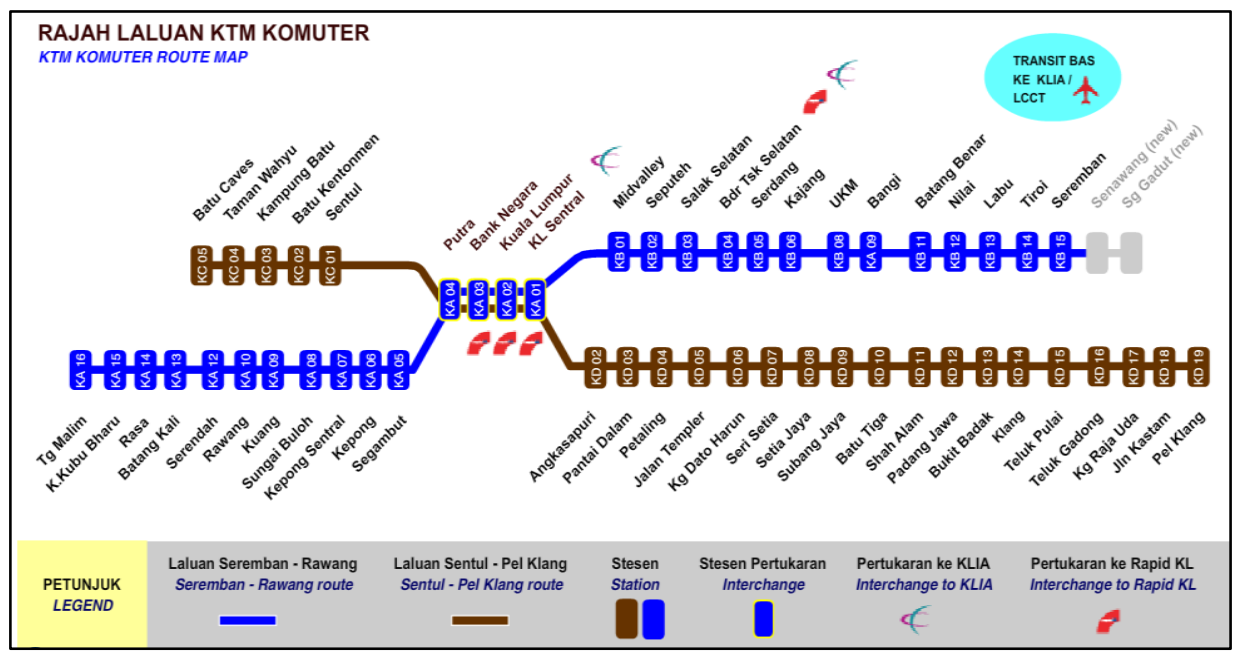

Figure 1: KTM Komuter route map

The commuter system, during the research undertaking, deploys threecar air-conditioned electrical multiple units (EMUs) with a single-car capacity of 50 to 100 passengers, totalling to about 150 to 300 passenger per EMU set. Park \& Ride facilities are provided at 43 stations at a nominal charge, with only 17 stations being serviced by feeder buses (KTM Komuter management, personal communication, 2013).

\section{KTM Komuter current networks}

With a track of more than $175 \mathrm{~km}$ (109 miles) KTM Komuter network has 53 stations (KTM Komuter management, personal communication, 2013). The networks ply through two cross-city routes, namely the Batu Caves-Pelabuhan Kelang line and Rawang-Sungai Gadut line, plus a shuttle service from Rawang to Tanjung Malim, which began service in April 2007. Transfer between the two main lines can be made at KL Sentral, Kuala Lumpur and Putra stations. Sameplatform or cross-platform interchange is available at Kuala Lumpur station. Passengers to and from stations between Rawang and Tanjung Malim must change trains at Rawang station. KTM Komuter has made shopping complexes and recreational centres more accessible. The Mid-Valley station, which opened in 2004 next to the Mid Valley Megamall, has proven to be regularly frequented. Other shopping centres located near KTM Komuter stations are Subang Parade and Carrefour Subang Jaya (near Subang Jaya station) and the MINES (near Serdang station). 
Syahriah Bachok, Mariana Mohamed Osman, Ummi Aqilah Khalid \& Mansor Ibrahim

Commuters' Perceptions on Rail based Public Transport Services: A Case Study of KTM Komuter in Kuala

Lumpur City, Malaysia

Passengers for Kuala Lumpur International Airport (KLIA) may take KTM Komuter to Nilai station and change to an airport bus, or change at KL Sentral station onto the dedicated KLIA Ekspres or change at Bandar Tasek Selatan interchange onto the KLIA Transit service. Interchange with RapidKL (light rail transit system) is also available at Bandar Tasek Selatan station for Ampang Line and at KL Sentral station for the Kelana Jaya line. Passengers may also transfer to the Ampang Line in the city centre at Bank Negara station by means of a 200-meter walk to the Bandaraya RapidKL station and interchange with monorail system at KL Sentral station. KTM Komuter tickets are sold at counters and via vending machines, available at all stations and halts.

Overcrowding during peak hours have been observed, hence the operator has introduced a new queuing system to help users line up when the trains were due to arrive (KTM Komuter management, personal communication, 2012). The lines were painted on the floor with three colour codes representing each of the train set, first implemented at KL Sentral station on 17 October 2008 (KTM Komuter management, personal communication, 2012). The operator has introduced but temporarily halted the express services between Sungai Buloh and Kajang stations and between Kuala Lumpur and Shah Alam stations during peak hours after 2008 (KTM Komuter management, personal communication, 2012).

\section{KTM Komuter issues and problems}

Several issues regarding KTM Komuter's performance have been identified from the contemporary literature (Bachok, 2010). The lack of integration between ticketing systems and inadequate supply of rolling stocks resulting in services being rescheduled from 15 minutes to 20 minutes have been highlighted (KTM Komuter management, personal communication, 2012). Other issues include low priority on maintenance, overhaul and repair programmes of the old rolling stocks resulting in a reduction of overall capacity especially during peak hours and feeder services (KTM Komuter management, personal communication, 2012).

This research limits itself to only focus on the following performance indicators: capacity, catchment areas, route, ticketing system, station facilities and incident and accident information dissemination. Performance evaluation is based on the users' perception and the management's prioritization of improvements to be realised during the GTPs implementation period. These measures provided the minimum level at which services are to be set against in determining the services' the success or failure. The indicators or measures 
reflect various levels of impacts on efficiency and effectiveness. Impacts on mobility can be reflected by passengers' socio-demographic and trip characteristics, including the origins and destinations. Impacts on accessibility can be represented by ridership, trip amounts or frequency or regularity and person-miles $/ \mathrm{km}$ travelled. Impacts on the users' satisfaction can be measured by the rating or ranking of services aspects, comfort, convenient, repeat use and willingness to switch from private vehicles. Overall performance evaluation can also be used to achieve specified standard and targets of the operators such ridership, revenue, return on investment, positive customer feedbacks and increased public sector subsidy.

A Guidebook for Developing a Transit (public transport) PerformanceMeasurement System prepared for Transit Cooperative Research Program Report 88 (2003) defines several performance measurements. These measurements and related issues are elaborated in the next sections. Selected measurements that can be conducted, suited for this research are:

i. capacity and frequency

ii. catchment areas

iii. route

iv. ticketing system

v. stations and facilities

vi. Incident/accident detection and dissemination.

\section{LITERATURE REVIEW}

\section{Sustainable Transportation}

Sustainable development is a concept explaining the environmental quality, social equity, economic vitality and the threat of climate change as used by the World Conservation Strategy (1987). The definition of "a development that meets the needs of the present without compromising the ability of the future generations to meet their own needs" has been subscribed to by the Brundtland Commission (1987). Today, the basic concept of sustainability deals with the recognition, evaluation and attempted mitigation of long-term impacts of human or developmental activity. Thus, there are "three pillars of sustainability" namely environmental preservation, economic efficiency and social equity (Tara, et al., 2009). 
Syahriah Bachok, Mariana Mohamed Osman, Ummi Aqilah Khalid \& Mansor Ibrahim

Commuters' Perceptions on Rail based Public Transport Services: A Case Study of KTM Komuter in Kuala

Lumpur City, Malaysia

Sustainable transportation within the context of sustainability adds the concept of transportation system effectiveness (Litman, 2005). Thus, impacts of the system on the economy, the natural (Jeon and Amekudzi, 2005) and built environments and the general social well-being. A recent study by the United States' Department of Transport indicated that a majority of the agencies related to transportation have expressed concerns over issues of the environment, the future needs and social equity (Jeon and Amekudzi, 2005). Strategies for sustainable transportation management that are related to public transportation are demand management strategies including modal substitution of private vehicles (cars, trucks, motorcycles and airplanes) by public transport, Para transit, ridesharing, walking, biking, rail and developments that promote walking and use of public transportation.

Substitution can be advocated by providing better modal options (offering services and improving public transport quality to attract travel to alternative modes) or through incentives for the use of alternative modes such as subsidies for users of preferred modes). Additionally, by improving accident/incident management methods, logistics and fleet management through advanced technologies for vehicle location and communication will improve public transport operation efficiency. Information technology-enhanced routing and scheduling can reduce the fuel needed for transport of both passengers and freight.

\section{User Satisfaction and Perception}

Satisfaction is an outcome of the experience that met the expectation (Engel, et al., 1995). Satisfaction of a single element may influence the overall satisfaction of the majority attributes of the goods or services consumed (Pizam, et al., 1978). Hence, it is essential to limit and discourage further dissatisfaction with one or more aspects of the train or trip making because if users felt so, they will be dissatisfied with the overall rail services of KTM Komuter. Moreover, satisfaction rate with each attribute of the trip making will create new perception of the services and this may influence tourists' intention to repeat their experiences travelling on the services (Swarbrooke and Horner, 2001).

Meanwhile, perception is a concept to express the process through which people see the goods or services (Schiffman and Kanuk, 1987). Pizam and Mansfeld (2000) further emphasized that perception is the process by which an individual receives, selects, organizes and interpret information to create a meaningful understanding or experience. Perception of an individual may differ from another, and has different meaning depending on the circumstances, 
culture, values and weather of an environment from which an individual originated. Perception may not be the actual truth. While expectation can also be interchangeably understood as perception, the former can be right or wrong. Individuals may find it disappointing if they could not expect what they frequently perceive to be accordingly as expected (Pender, 1999). Hence, KTM Komuter users might have positive or negative perception if perceived and expected services do not perform as what they aspired. These included the following attributes.

i. capacity and frequency

ii. catchment areas

iii. route

iv. ticketing system and travel time

v. stations and facilities

vi. incident/accident detection and dissemination

\section{Capacity and Frequency}

Capacity and frequency are two essential performance indicators of public transport service levels. The variables tested in this study are the number of passengers that can be accommodated by the train cars-set throughout the services duration, in particular, during peak-hours. For the current three-car EMUs, the total capacity ranged from $50-100$ seated and standees depending on the makes and models of the car-set. As such, for a three-car set, a capacity of $150-300$ riders can be accommodated at any particular time.

The supply of physical rolling stocks predicted in the early 1990s has reached capacity for KTM Komuter services during the early years at the turn of the century. As such, from 2005 onwards, pressures to increase capacity have been experienced by KTM Komuter. With only 36 EMUs, servicing nearly 60,000 passengers daily, the operator could not single handedly cater the expanding demand. Additionally, more and more rolling stocks have reached their estimated lifecycle, with more than a quarter EMUs needing scheduled maintenance, repairs and overhauls. At one point in time during 2008 onwards, KTM Komuter services with a scheduled of 4 services per hour (15 minutes headways or intervals) were operating with only 28 EMUs, hence an overcapacity of more than 15,000 passengers. The published scheduled of services have been revisited and revamped from 15 minutes per service to 30 minutes and later 20 minutes headways or intervals. In other words, the train frequency has been reduced from 4 services per hour to only two and three respectively. The existing scenarios have indicated the need to increase the 
Syahriah Bachok, Mariana Mohamed Osman, Ummi Aqilah Khalid \& Mansor Ibrahim

Commuters' Perceptions on Rail based Public Transport Services: A Case Study of KTM Komuter in Kuala

Lumpur City, Malaysia

number of capacity, the restructuring of services frequency to better reflect the available capacity, the replacement of overhauled rolling stocks and an improved and more frequent maintenance and repair culture among the operator's technical and engineering departments; simultaneously to meet the increasing demand levels.

Today, KTM Komuter's annual ridership was at 36.557 million passengers (Ministry of Transport Statistics, Malaysia, 2008). This number can be translated into about 100,000 riders per average day. Demands could not be met by the current rolling stocks (at the time of writing only 26 three-car EMU sets were operational and track-worthy) and available capacity because some units are still undergoing overhaul programmes and the shortfall of old and disposed off units have yet to be replaced. Passengers have largely complained about the lack of comfort and convenience as well as overcrowding of the current units and locomotives. Most of the users claimed to have experienced low level of convenience due to the overloaded coaches and perceived low frequency especially during peak hours.

\section{Passenger Catchment Areas}

Another issue faced by KTM Komuter (KTM Komuter management, personal communication, 2012) was the low frequency and quality of feeder services provided at most of the stations. In Kuala Lumpur region, feeder services are offered by medium buses with capacity of 25 seats and 20 standees, often not in integration with the rail operations. In the case of KTM Komuter, it does not have its own feeder services, and the buses are often operated by independent bus companies or by RAPIDKL (a conglomerate company managing both city buses and light rail services). This is an obstacle to increase the catchment of passengers around the selected residential buffers for instances $5 \mathrm{~km}, 10 \mathrm{~km}$ or $15 \mathrm{~km}$ around the stations. The situation was made worse for the captive riders than choice riders due to inaccessible stations by personal mode of transportation. It was not clear how the rates of catchment were calculated during planning and development of KTM Komuter system, because there was no systematic documentation of catchment studies (KTM Komuter management, personal communication, 2012). Other issues identified during the board meetings and interviews with KTM Komuter management and users surveys have also included that:

i. the catchment areas of KTM Komuter and its coverage were still inadequate, with stations being planned and developed at unstrategic locations of low population density and limited feeder services 
ii. the lack of parking facilities and inadequacy and sub-standard feeder services have exacerbated the dwindling number of passengers at certain stations

iii. The inadequate catchment of passengers of certain stations has resulted in low viability and feasibility of providing sustainable feeder services and high quality accessibility.

The geographical boundaries were usually used to define catchment areas. From the centroid of stops, halts or stations, analysis of potential number of passengers can be made in accordance with the land use and population density. Using Geographical Information System (GIS) tools, the catchment falling under the determined radii which are buffers around the selected stations (centroid) or street networks (links) can be determined. GIS is able to input the layer of information regarding travel demand to the geographical catchment area. Additionally, time-based accessibility index can also be applied in monitoring the performance of KTM Komuter services. One hindrance to the smoothness of planning and implementation of development and construction for facilitating feeder services is the cost of acquiring extra land surrounding the stations. Currently only 38 out of the 53 stations provide park and ride facilities. Plans are under way for additional 15 stations to benefit from additional parking provision. Other improvements planned are the increasing frequency and quality of feeder services and stations' upgrades. At the time of writing, feeder services operated at a headway ranging from 30 minutes to more than an hour for selected routes and neighbourhood coverage.

\section{Routes}

The public transport riders or patrons generally have one purpose in mind, which is getting from one origin to a destination on public transport with the greatest ease and convenient possible. The customers' ease of transferring from one public transport system to another is termed as connectivity (Wen-Ji, 2003). Connectivity is basic to using or providing public transport service. Connectivity is what most personal transport modes or private vehicles can offer better, hence a selling point for a public transport operator offering this kind of alternative mode service. Therefore, it is essential for the public transport operators, public agencies and organizations involved in funding and promoting public transportation to heed connectivity from the customers' viewpoint (both new and experienced riders and non-users). 
Syahriah Bachok, Mariana Mohamed Osman, Ummi Aqilah Khalid \& Mansor Ibrahim

Commuters' Perceptions on Rail based Public Transport Services: A Case Study of KTM Komuter in Kuala

Lumpur City, Malaysia

Currently, KTM Komuter has two main routes. Along these routes, there exist four interchange stations. Three stations provide transfer facilities to RAPIDKL services and one to KLIA Ekspres and KLIA Transit routes as well as monorail service. Four new stations along the Sentul-Batu Caves route $(7.2 \mathrm{~km})$ were completed in 2011. The project which cost more than RM515 million included electrification, double tracking and refitting of the old existing track, signalling, communication and construction of stations: Batu Cantonment, Kampung Batu, Taman Wahyu and Batu Caves. In the near future, Mass Rapid Transit (MRT) system proposal will provide two more interchange opportunities namely at Sungai Buloh and Kajang districts. With the opening of stations: Senawang and Sungai Gadut along the Rawang-Seremban route, the Klang Valley-Seremban region is properly accessed by heavy rail network. Long term planning would eventually lead to creation of circular lines and sublines of smaller-scale routes with the Greater Kuala Lumpur Region, hence completing the integrated system and network coverage of passenger rail services envisaged by many in the industry (KTM Komuter management, personal communication, 2012).

\section{Ticketing System and Travel Time}

Since its first operation, KTM Komuter has adopted the paper ticket system. It later introduced the 'Touch n Go' pre-paid stored value plastic-card-based ticket system to overcome some of the problems relating to inadequate ticket counters and high utilization of ticket vending machine during peak hours. However, the introduction of the new system has not improved much of the issue identified with the initial purposes, but rather increased the waiting time and overall journey time. Even with the new system, total travel time has since been in excess of 25 per cent due to waiting time for tickets transactions and idle time spent for rail cars to arrive at stations or platforms. In other words, to reach the destination at a designated arrival time, passengers have to begin the journey 25 per cent earlier than the normal departure time. Ticketing issue is also related to the fragmentation of the public transport system, each operator adopting a separate non-compatible system and diverse collection systems. It is envisaged that an integrated smart ticketing and contactless ticket system with features such as those of Oyster Card (London), EZ-Link (Singapore) and Octopus (Hong Kong) will be able to replace all the different ticketing system of bus and rail systems across Klang Valley in the near future. 


\section{Station and Station Facilities}

Review of literature (Bachok, 2010) has also identified that the difficulties of transferring between and among many rail and road based public transport systems could hinder smooth and safe travels, compounded by the limited number of station termini with effective and efficient interchange facilities. This decreased the attractiveness of public transport and eventually reduced the options of users to undertake the whole or most of the journey legs by public transportation (Wen-Ji, 2003).

Servicing about 53 stations and localities, KTM Komuter trains now traverse over $210 \mathrm{~km}$ of networks. Some of these stations were planned and designated accordingly as transfer or interchange stations. KL Sentral, Bandaraya, Kuala Lumpur, Bandar Tasek Selatan and Putra stations are such as those. Along the newly extended route, passengers from the northern suburbs such as Tanjung Malim must transfer at Rawang stations to continue their journey southwards and vice versa. Whilst these stations may have some features for transfers, they were lacking much in seamless and smooth pedestrian interchanging experiences to both rail and road based public transportation. First, the stations connection with the other bus or rail system can be of great walking distance under extreme weather of Malaysia (heavy rain and high humidity under scorching sunrays), not weather-proofed and disabledfriendly and can also be unsafe, especially for female users travelling during late evening.

Many stations with so-called transfer facilities, lack the transit-oriented development interchange characteristics, including single integrated ticketing system. Many of these stations are located where population densities are low, retail and business functions are limited to induce walking culture and do not serve the high density residential areas, where many captive riders often dwell in. It is therefore, essential to evaluate these stations' characteristics and propose schemes to uplift the stations' features and facilities so that minimal qualities of transit-oriented development interchanges can be ensured.

\section{Incidents/Accidents Detection and Related Information Dissemination}

Incidents and accidents can be two important issues hindering the efficient, smooth and safe rail journey experience. On average, from year 2004 to 2006, approximately three incidents and/or accidents have been recorded annually within KTM Komuter services (Ministry of Transport, 2006). Most of them involved intercity trains that shared the same track system with the KTM Komuter service. The impacts were severe especially when services of 
Syahriah Bachok, Mariana Mohamed Osman, Ummi Aqilah Khalid \& Mansor Ibrahim

Commuters' Perceptions on Rail based Public Transport Services: A Case Study of KTM Komuter in Kuala

Lumpur City, Malaysia

commuter trains during peak hours have already been delayed due to the backlog of existing rolling stocks. In most instances, passengers at terminals, stations and on-board the trains were not promptly informed of these occurrences and left un-attended with alternatives and possible responses.

Therefore, a study on the evaluation, prediction and emergency strategies such as diversion of routing and rescheduling is highly timely. In the least, an assessment into how passengers and commuters were supposedly reacting to such delays can be made and improved by interim dissemination of information and prescriptive responses to alternative or choices. This is an area lacking in the literature of public transportation in Malaysia, and this research specifically deals with this research realm.

\section{METHODOLOGY}

The study employed three methods of data collection. First, is the review of literature to set the scene for problem statement formulation. Second, the research team attended meetings of the board of management and held discussion session with KTM Komuter management team. From this method, various personal communications resulted in data gathering that was not made available in documented resources. Finally, primary data was also collected through an on-board intercept survey using pre-tested and carefully designed questionnaire forms. Observation of passengers' characteristics, stations attributes and trip making behaviour has further confirmed the responses made by the samples surveyed.

On-board intercept survey has many advantages over other methods in various aspects, after considering the values, cultures, beliefs, attitudes and weather conditions of the general Malaysian public. First, on-board intercept survey has been found to be particularly effective compared to household survey due to the avoidance of recall type of questions, especially those related to public transport trip making experiences and perception. Second, it is more effective because immediate screening of prospective public transport users can be ensured. Since, all on-board travellers are using public transport; samples can be as highly as 100 per cent representation of KTM Komuter users, regardless of being a first timer or otherwise. On-board intercept survey is also more effective than on-line, internet or computer-aided questionnaire survey because targeted samples would include all user types and would not exclude those without internet, computer or wired services. Finally, compared to at-station, at-terminal or at-platform survey, on-board intercept survey has been found to be very 
efficient since it minimizes rates and chances of samples refusing or declining to response to questionnaire due to anxiety resulting from arriving or departing trains at the station or terminal or platform. In addition, having experienced real or actual trip making would increase the validity and reliability of samples' answers because they can easily and comfortably relate those questions with their current trip making activities.

Some 1200 questionnaire forms were distributed to passengers on-board the trains on various survey days and time period, during two phases: pilot survey and comprehensive survey. Some 1100 forms were completed and returned. Data entry and cleaning have found that some 1000 samples were useful and meaningful for data analysis purposes. The selections of respondents were based on a systematic randomized probabilistic sampling and identification of origin and destination of these passengers as screening process. Twenty enumerators were employed for each morning and afternoon survey period. A minimum of two enumerators were stationed at each door of each train car to observe and select the prospective samples. Using the $5^{\text {th }}$ interval, each respondent was identified at stations beginning at Batu Caves, Tanjung Malim, Rawang, Sungai Gadut Seremban, Sentul and Pelabuhan Kelang, then was selected, approached and handed the questionnaire to be completed. The $5^{\text {th }}$ interval was selected because it was deemed that biasness and skewness of samples can be avoided during selection, be them travelling in groups or individually. In other words, even if a large group was travelling chances of one of the members being selected can be ensured to be equal to that of an individual or a smaller group. Most of the time, if a party of five or more was travelling, the members might contemplate on the travel time and costs, since it can be more effective and less costly to travel in private vehicles such as cars compared to using public transport.

It was deemed faster and more effective for the surveys to be guided and forms to be completed by the enumerators who conducted the surveys as an information trips narration with the respondents. Using this method, target samples can respond more effectively in expressing their perception and satisfaction levels, without the distraction of reading, contemplating and writing the answers to the questions posed in the forms. Since the questions were comprehensive and the pilot survey indicated a minimum of 5 to 7 minutes were required to complete the forms, a screening activity of selecting only passengers travelling of a minimum of 7 minutes or 5 stations in the city centre or 3 stations in the outer suburb was conducted, before beginning the comprehensive intercept surveys. 
Syahriah Bachok, Mariana Mohamed Osman, Ummi Aqilah Khalid \& Mansor Ibrahim

Commuters' Perceptions on Rail based Public Transport Services: A Case Study of KTM Komuter in Kuala

Lumpur City, Malaysia

The analysis and evaluation of data related to customers' satisfaction in terms of punctuality, delays, total travel time, service frequency, ticketing system, safety, convenience and facilities were carried out afterwards. Data was recorded in Statistical Package for Social Science software (SPSS), to assist in various analysis activities. Several techniques required at this stage were qualitative, quantitative, univariate and bivariate analyses. Consequently, findings were presented based on detailed and thorough descriptive and inferential analysis in the next section.

\section{ANALYSES}

\section{Respondents' socio-demographic characteristics}

Of the 1000 samples, some $41 \%$ of the respondents were males. This reflected the composition of passengers and the selection of railcars during the survey periods. The majority was local users $(92 \%)$ with at least a college or university qualification (32\%). The mean age of travellers was 30 years old, indicating a young, able-bodied and mobile sample grouping travelling on his or her own (more than 90\% sample travelled alone). The average monthly household income reported by the respondents were RM2870 (USD 913), indicating a slightly higher income groups than the average population of Malaysia (GDP USD7,000 per annum or USD 585 monthly or RM 2100 monthly). A majority of the respondents were choice users, having owned or an access to alternative vehicles for similar types of trips undertaken during the survey periods. One in five had no access to an alternative mode for trips made, or in other words, captive users.

All the socio-demographic characteristics have bearings on the generalization of the findings and recommendations to be made in the following sections. Samples' characteristics would implicate certain patterns, skewness and tendency towards the kind of responses gathered in the sections to follow.

\section{Respondents' trips characteristics}

On average, the 1000 samples used KTM Komuter approximately once in a month during 2012, indicating a relatively low usage rate, not as commuters. During the surveys, $90 \%$ of respondents have been intercepted during both am and peak off peak hours due to several logistic reasons. As such, only one in ten respondents were regular or daily commuters. Routes along which they travelled were also not equally distributed with more respondents intercepted 
northwards from Sungai Gadut station towards Rawang and Tanjung Malim (65\%) and southwards from Batu Caves to Pelabuhan Kelang station (48\%) possibly because of the longer distance and time of the journeys. Only $7 \%$ were intercepted during journeys from KL Sentral station to Batu Caves due to the short journeys involved.

A majority of the respondents were on homebound journeys (from and to home, $53 \%$ and $24 \%$ respectively). Similarly, journeys made from workplaces and education institutions were $19 \%$ and $15 \%$ respectively, while journeys to these to destinations were about $24 \%$ and $10 \%$ respectively. These three journey types and three main activities were the reasons for patronage of KTM Komuter by young and commuting riders.

Access modes to stations were friends' and family members' vehicles (24\%), feeder buses (19\%), own cars (17\% used park and ride facilities) and pedal power (walking 12\%). Meanwhile, egress modes to final destinations were friends' or family members' vehicles fetching the passengers $(31 \%)$, pedal power (walking 26\%) feeder buses (20\%) and other connecting train systems. It can be seen that stations may not be highly accessible by other modes compared to private vehicles, implicating the rates and coverage of ridership. Even though catchment may be larger than or extended beyond the current ridership radii, lack of and inaccessible feeder buses might contribute to the less than optimal ridership from these stations.

Passengers' perception on the various measurement of performance can be highly influenced by the above discussed characteristics of trip and trip making.

\section{Passengers' Perception of KTM Komuter's Substitutional Mode Availability}

Passengers were able to substitute KTM Komuter trip for other modes on almost all days of the week. For instance, they can drive their own vehicles, use other rail systems, ride the buses and motorcycles $(60 \%$ to $75 \%$ of all trips can be made using these vehicles on Mondays through to Fridays). The highest substitution rate was possibility on Wednesdays with only $25 \%$ of riders being captive. Some $17 \%$ of KTM Komuter riders used the park and ride facilities and indicated that parking at a specific station was not as important as finding a space for parking. Majority ( $90 \%$ and $81 \%$ respectively) had no problems with parking fee rates and safety levels in parking areas. 
Syahriah Bachok, Mariana Mohamed Osman, Ummi Aqilah Khalid \& Mansor Ibrahim

Commuters' Perceptions on Rail based Public Transport Services: A Case Study of KTM Komuter in Kuala

Lumpur City, Malaysia

\section{Passengers' Perception of KTM Komuter's Levels of Services}

Capacity, routes and frequency

During peak periods, only $58 \%$ of respondents were able to board the first trains they encountered at the platform. In the morning peak period, $42 \%$ of the respondents were only able to board the second train services, while $1 \%$ had to wait for third trains to resume their journeys.

During evening peak periods, the situation got worse. Approximately $23 \%$ respondents had to board the second train while $2 \%$ had to wait for the third train to continue with journeys.

At present, trains were scheduled to service at a frequency of 3 per hour or 20 minutes headways or intervals. This meant that theoretically, a passenger has an average waiting time of between 10 to 15 minutes. Previously, the published scheduled had set the frequency at 4 per hour or 15 minutes headways or intervals, with an average waiting time of 7 to 12 minutes. However, in view of the reduced capacity due to overhauling, repair and maintenance activities, the revised frequency was established. Passengers stated that they had complained about the reduced capacity and changes in frequency. However, the situations did not get any better, and since 2008 the reduced frequency got worse, with a perceived increase in waiting time to more than 20 minutes on average. During the survey periods, the research team experienced, first hand, an average waiting time of more than 20 minutes, with an isolated excessive delay during two occasions of more than 2 hours waiting time.

The increased waiting time can be explained partially by the changes in capacity from 36 EMU sets in the 1990s to only about 28 EMUs operating at the turn of the century. Hence, perceived and actual frequency indeed has actually worsened, and headways or interval of 20 minutes could not even be met prior to the initiatives of GTPs by the government.

Around $74 \%$ respondents agreed that the current routes were adequate. Majority of the respondents $(69 \%)$ also agreed that the additional routes including Seremban-Sungai Gadut and Rawang-Tanjung Malim have benefitted them in the sense of greater catchment of long distance destinations and trips being perceived to be closer than before. Only 55\% of the samples agreed there was a need for route expansion to increase accessibility by population living in the outer suburbs. These respondents even suggested, among others, an extension of route to Sungai Besar, Kuala Selangor, Ulu Yam, Tampin, Gemas and Johor Bahru. Majority respondents (74\%) respondents believed that the current capacity was insufficient. These users suggested the increase in capacity 
will reduce many negative impacts including overcrowding during peak periods, delays and irregular schedule in adherence.

Safety and security perception on-board trains, stations and platform facilities Safety and security were two important aspects perceived by the train users surveyed. However, there were not as important as improving the services frequency and scheduling, based on the responses of the users surveyed. At stations, three quarters of the respondents felt they could travel alone without being accompanied. This highly perceived level of safety and security was also supported by the idea that only half respondents believed that they should be cautious about the surrounding environment and be wary of their belongings. Most of the time, half of the respondents felt safe waiting at lowly-lit or enclosed areas of the stations. While waiting for the train to arrive, more than half also managed to find seats.

Overall opinions about the station and facilities were satisfactory. A high majority of users surveyed perceived the stations were clean and wellmaintained. The ventilation system was also satisfactory. Only 55 respondents had experienced incidents in the last couple of years. $4 \%$ experienced or witnessed snatch theft while $1 \%$ experienced sexual harassment at the stations. Whilst $58 \%$ of the respondents saw security officers patrolling the stations, they also suggested that peak hours needed more frequent surveillance to ensure safety and security of passengers.

On-board trains, the majority of the respondents (82\%) also felt safe travelling alone. Half of them believed that they should be wary of the surrounding and of their belongings. Approximately 5\% of the respondents had experienced or witnessed snatch theft and $7 \%$ had experienced sexual harassment on-board the trains.

Ladies' coaches were used by $61 \%$ of the respondents surveyed. The reason for the preference was that ladies' coaches ensured safety and comfort. Most respondents were first informed of these services by their friends and families. When asked about the presence of a male user in the coaches, $58 \%$ of female users stated that they felt uncomfortable about it. Similarly, 95\% of ladies coach users felt safe travelling alone. Likewise, $73 \%$ felt there was a need to be wary of the surrounding and their belongings.

Ladies coaches users surveyed felt safe even though trains were crowded, especially during peak periods. More than half female respondents stated they were able to find seats when travelling in a ladies' coach. $82 \%$ preferred to continue their journeys even though no ladies' coach was provided 
Syahriah Bachok, Mariana Mohamed Osman, Ummi Aqilah Khalid \& Mansor Ibrahim

Commuters' Perceptions on Rail based Public Transport Services: A Case Study of KTM Komuter in Kuala

Lumpur City, Malaysia

within the train sets arriving at the station. $79 \%$ also stated that they would resume using KTM Komuter, even if the ladies' coach provided within the train sets arriving at the station were full. Some $14 \%$ of female respondents suggested that more ladies' coaches be provided in the future.

Overall, the respondents (86\%) felt comfortable travelling with $K T M$ Komuter. Seats have also been suggested to be reconfigured and redesigned to instil more privacy and to provide more spaces for increased number of passengers. Adding seats were suggested by some $10 \%$ while the remaining proposed regular maintenance and cleaning of the train.

Crowding was not especially a concern of some $91 \%$ of the respondents. Peak hours may be more uncomfortable (4\%) and at all time, it was suggested that no crowding be allowed (3\%). One in eight perceived that air-conditioning onboard train needed maintenance, because it was especially warm and uncomfortable during peak hours and crowded situations. The majority ( $96 \%$ to $97 \%$ ) perceived the trains were comfortable, including doors, windows, movement within a coach and inter-coaches.

\section{Information, ticketing and fares}

Respondents' first encounters with KTM Komuter services were the results of friends or family members introducing them to the system (67\%). Around $12 \%$ of the respondents reported that they were first made aware of KTM Komuter services by the electronic media including the television. The remaining $21 \%$ accessed the print media to become aware of KTM Komuter services. Majority of the respondents $(73 \%)$ perceived that the information has assisted their way finding, with less than 2 minutes taken to correctly find their directions.

Before embarking on a trip, about $33 \%$ sought KTM Komuter services from the service guide leaflet, while $32 \%$ referred to paper timetables. Approximately $25 \%$ of the respondents accessed the internet and other $10 \%$ telephoned the call centre to find out about KTM Komuter services. At the station or terminal, two in three respondents (54\%) accessed travel information from the platform information displays. About two in ten respondents (22\%) utilized the static directions and signs to access the train services information. The remaining respondents consulted the platform and counter staff (7\%) and public address system (4\%).

On-board, passengers surveyed had two choices of information provision. Nine in ten respondents (92\%) listened attentively to on-board announcement to orientate themselves in determining the stations of arrival. The 
remaining $8 \%$ respondents studied the route maps to identify their current locations. $80 \%$ respondents perceived that the existing signage directions were adequate and $79 \%$ respondents agreed that both platform and on-board signage were adequate.

Approximately $24 \%$ to $33 \%$ of the respondents experienced some confusion when comprehending the information provided. Among the reasons were that the signage and information were not continuous in directing to station or destinations, the location being not suitable and the lack of information about the current location. Similarly, unclear announcement at platforms and onboard had led to these confusions. The respondents suggested, among others:

i. clear announcement and update information at platform, station and onboard trains to be provided

ii. more detailed information on displays to be provided

iii. information and other facilities need to be maintained

iv. maps and words need to be in larger fonts for legibility purposes

v. customers' feedback needs to be responded to promptly and staff need to be more customer-friendly

vi. electronic displays can be adopted for displays onboard train

vii. more comprehensive and prescriptive information to be provided at interchanges stations

Majority of respondents (83\%) surveyed, purchased the one-way conventional paper ticket. Only $1 \%$ utilized the return and weekly ticket facilities. The remaining $14 \%$ and $1 \%$ respondents used the smart card 'Touch $n$ Go' system and staff passes respectively. Majority of the respondents (96\%) had purchased the tickets at the manual counters. Only $1 \%$ utilized the vending machine facilities. Almost all activities relating to finding ticket counters, purchasing and payment of tickets took less than 2 minutes to complete respectively. However, purchasing a ticket from the vending machines took a little bit longer i.e. 5 minutes, similar with entering the platform after purchasing the tickets. Purchasing prepaid tickets also took 3 minutes. The users surveyed recommended all activities relating to ticketing be undertaken within 2 minutes or less.

Vending machine breakdowns were rare phenomena in many stations. However, 35\% of the respondents recalled having experienced this. They eventually bought the tickets manually at the counters. The stations involved were: Batu Caves, Taman Wahyu, Sentul, Bank Negara, KL Sentral, Shah 
Syahriah Bachok, Mariana Mohamed Osman, Ummi Aqilah Khalid \& Mansor Ibrahim

Commuters' Perceptions on Rail based Public Transport Services: A Case Study of KTM Komuter in Kuala

Lumpur City, Malaysia

Alam, Tanjung Malim, Rawang, Segambut, Mid Valley, Serdang, Kajang, UKM, Batang Benar, Nilai dan Seremban.

Delays

Approximately three out of four of respondents have experienced delays in the last couple of years. Actual waiting time varied from generally an average of 17 minutes during week days with the exception of Fridays to 39 minutes during the weekends (read also section on capacity, routes and frequency). From the $79 \%$ who revealed that they experienced delays, some $77 \%$ recalled receiving information about the delays. From this group of respondents the majority (74\%) stated that delay information was conveyed through the public announcement system, while some $22 \%$ sought the display message signs. The majority of those who experienced delay had waited for the trains to resume to its normal services.

During peak periods, users' surveyed perceived waiting time were higher than those of off peak periods. These users perceived that they waited for a range of 23 minutes to 68 minutes during these periods. On a typical week, the performances of services were also evaluated. Normal trips with train arrival and departure generally on time or within 5 minutes of published schedule were agreed by some $20 \%$ of the respondents for all day in the typical week. Some $6 \%$ of respondents stated that trains were delayed more frequently on Fridays of a typical week. Some 5\% respectively indicated delays occurred more frequently during weekends of a typical week. Delays for both Tuesdays and Wednesdays of a typical week were indicated to occur more frequently by only some $3 \%$ of the respondents respectively. Only $4 \%$ perceived that delays occurred more frequently on Mondays and Thursday of a typical week. Some $1 \%$ perceived that services were frequently cancelled on all days of a typical week. Approximately $47 \%$ to $55 \%$ of respondents perceived that trains were running on a frequency of 15 minutes while less (17\% to $28 \%$ ) believed that trains run on a frequency of 30 minutes.

On a typical week too, only $1 \%$ of respondents perceived that trains were arriving ahead of the scheduled time on Mondays, $3 \%$ on Wednesdays and none on other days of a typical week. However, as much as $5 \%$ believed that trains were departing from stations before scheduled time on Wednesdays. On the other days of a typical week, only $1 \%$ respondents perceived that trains were departing ahead of scheduled time. The majority (54\% to $62 \%$ ) perceived that on a typical week trains were departing around 5 minutes after scheduled time from the stations. Variation from scheduled was more persistent on Wednesdays (62\%) compared to Sundays and Tuesdays (55\%) respectively. More than a 
third of respondents were in the opinion that trains were departing around 10 minutes behind schedule on all days of a typical week. The variation was more persistent on Mondays, Tuesday and Wednesdays (35\%) respectively compared to $27 \%$ on Sundays of a typical week. Between $5 \%$ and $12 \%$ of respondents perceived that trains were departing from stations more than 10 minutes behind schedule, especially persistent on Sundays.

Overall perception of services

It can be seen that there were variations of the perceptions and satisfactions with the services. Mixed perception of the waiting times and train delays could be due to the socio-demographic and trips characteristics of passengers, as discussed earlier. Nevertheless, it is imperative for this research to emphasise that most of the passengers can recall being delayed and can express their dissatisfaction with KTM Komuter. Hence, a rather overall negative perception of the commuter rail services.

In general, one in four respondents viewed KTM Komuter services to be delayed. Some $9 \%$ indicated crowding as a major issue of services. Approximately $3 \%$ perceived that the services needed overall improvement, while the remaining was satisfied with the services. Only $1 \%$ of the respondents believed that the services have improved since the first time they used it. On the other extreme, only $1 \%$ strongly argued that the services were horrible and could not be improved in the future.

\section{Overall Findings}

The surveys have preliminarily concluded the following findings:

i. Train services were infrequent compared to the published schedule

ii. Train services seldom adhered to schedule

iii. Train services were susceptible to delays and frequently delayed

iv. Information during delays were currently provided but inadequately, in the sense of prescribing detail reasons for delays and alternative actions to be undertaken during severe cases of delays

v. Train capacities during peak hours have reached its maximum, and waiting time of more than 30 minutes were intolerable for some commuters and users. In many cases, users had to wait for the second trains to board during peak hours

vi. Train capacity during peak hours were also insufficient in the sense of spaces provided. The current 3-car system needed extending and 
Syahriah Bachok, Mariana Mohamed Osman, Ummi Aqilah Khalid \& Mansor Ibrahim

Commuters' Perceptions on Rail based Public Transport Services: A Case Study of KTM Komuter in Kuala

Lumpur City, Malaysia

suggestions have been to increase up to three more coaches per service run.

vii. Other station facilities improvements were currently not critical, although the perception about the services will be further improved in conjunction with increased capacity.

viii. In the short run, increasing capacity was the immediate action to be taken, while in the long run overall upgrading of services levels need to be ensured too.

\section{OUTPUT OF STUDY}

The findings from this research will help to create a set of alternatives in improving the performance of KTM Komuter. The recommendations and suggestions assisted by strong justifications will indeed assist the service providers, decision makers, stakeholders and responsible authorities to provide a better and more efficient public transportation system.

The study on the users' perception of KTM Komuter services prior to the improvements (additional coaches for KTM Komuter) made based on the National Key Results Areas (NKRAs) under GTPs have indicated several directions of improvements (Malaysian Government, 2011). From the analyses, the respondents have a general dissatisfaction with the current levels of services. Areas of their concerns included services frequency, adherence to schedule and delays. Passengers surveyed also put forward several recommendations to improve the current services. These included:

i. to increase train frequencies from the current 30 or 20 minutes headways or a frequency of two or three services per hour to 15 minutes headways or a frequency of 4 services per hour

ii. to increase train capacity from 3-coaches to 4-coaches or more system

iii. to increase rates of schedule adherence among train systems

iv. to frequently maintain the existing rolling stock to ensure each train set performs its best services in timely manner

v. to pay appropriate heed to passengers' complaints and feedbacks so that only important improvement areas be immediately addressed to in time of limited budget allocation for public transport industry. 
The researchers hope that necessary, prompt and timely actions are undertaken to ensure that passengers' satisfaction and loyalty to KTM Komuter services are kept to their maximum level. However, the willingness rates of repeat use $(11 \%)$, so far has indicated otherwise. Hence, the prioritization and implementation of the above listed recommendations can be made immediately. In the least, the choice and captive riders should perceive that KTM Komuter is still a relevant and an attractive alternative to other private modes and remain loyal to the services.

\section{CONCLUSIONS}

This research derives its basis from the viability of KTM Komuter as a sustainable transportation mode. Rail-based transportation has been recognised as one of the many strategies for alleviating traffic congestion in urban areas, and a means of reducing peak hour traffic. The findings from this research will help create a set of alternatives in improving the performance of KTM Komuter. The NKRAs' objective of modal split of $25 \%$ (of public transportation share) can be achieved if improvements can be carried out in the services levels of KTM Komuter including rolling stocks, scheduling and dispatching, signaling and track maintenance, public transport information systems, station facilities, seamless ticketing and improvement of users' satisfaction. The recommendations and suggestions assisted by strong justifications will indeed help the service providers, decision makers, stakeholders and responsible authorities provide a better and more efficient public transportation.

This paper attempted at presenting an overview of the users' satisfaction with KTM Komuter services and how KTM Komuter services contribute in achieving sustainable transportation in Malaysia. Satisfaction of the public transportation services can be partially represented by the users' perception of KTM Komuter services. Since the findings have indicated relatively infavourable perception, therefore, it has been assumed that the satisfaction levels of public transportation in Kuala Lumpur were also relatively lower. Despite the fact that the study being a work in progress, it is still expected to contribute to the understanding and potential of KTM Komuter in alleviating, if not solving, peak hours traffic congestion, and thus promoting more sustainable transportation in Malaysia. The contributions are reflected by the generalization of findings, recommendations and prioritization of several aspects of services as have been discussed previously. 
Syahriah Bachok, Mariana Mohamed Osman, Ummi Aqilah Khalid \& Mansor Ibrahim

Commuters' Perceptions on Rail based Public Transport Services: A Case Study of KTM Komuter in Kuala

Lumpur City, Malaysia

\section{ACKNOWLEDGEMENT}

This study was undertaken with financial support from the KTM Komuter and the Government of Malaysia. The designation of geographical entities in this paper, and the presentation of the material, do not imply the expression of any opinion what so ever on the part of KTM Komuter.

\section{REFFERENCES}

Amekudzi, A., and Jeon, C.M. (2007). Evaluating Transport Systems Sustainability: Atlanta Metropolitan Region. Presented at 86th Annual Meeting of the Transportation Research Board, Washington, D.C.

Amshida A. R. (2011). KTMB Komuter: Avoid overloading of coaches. [July 10, Accessed $10 \quad$ October $2011 \quad$ at http://e.nst.com.my/nst/articles/19komter/Article]

Bachok, S. (2010) Behavioural Impacts of Integrated Public Transport Information System, unpublished PhD Thesis, University of South Australia, 2010, Adelaide.

Behwal R., and Behwal S. (2010). Public Transportation Services in Oman: A Study of Public Perceptions, Journal of Public Transportation, Vol. 13, No. 4: 2010

Daekin E, (2001) Sustainable Development and Sustainable Transportation: Strategies for Economic Prosperity, Environmental Quality, and Equity. Institute of Urban and Regional Development, University of California, Berkeley.

Department of the Environment (1994) Malaysian Environmental Quality Report.

Dinesh M., and Geetam T., (1999) Sustainable Transport Systems: Linkages between Environmental Issues, Public Transport, Non-Motorised Transport and Safety. Economic and Political Weekly, Vol XXXIV:25, pp 1589-1596.

Dridi, M., K. Mesghouni, and P. Borne. (2005). Traffic control in transportation systems. Journal of Manufacturing Technology Management 16 (1): 53-74.

Engel, J.F., Blackwell, R.D. \& Minard P.W. (1995) Consumer Behaviour, Texas, The Dryden Press.

Malaysian Government (2011) Government Transformation Programme: Malaysia - Pemandu, www.pemandu.gov.my/gtp/ 
Jeon, C. and A. Amekudzi (2005). Addressing Sustainability in Transportation Systems: Definitions, Indicators, and Metrics. Journal of Infrastructure Systems, ASCE, pp. 31-50.

KTMB (1996) KTM Komuter:Malaysia's first electrical rail, Kuala Lumpur.

KTM Komuter Board Meeting (2012) Personal communication.

KTM Komuter Board Meeting (2013) Personal communication.

Lem, L.L., Li, J.L., \& Wac, M. (1994) Comprehensive Transit Performance Indicators. Retrieved February 29, 2012 from http://www.uctc.net/

Lester Kong (2010) http://klnportal.kln.gov.my

Lester Kong (2010) The lifeline of a nation. The Star. [Accessed 10 October 2011, at http://thestar. com. my/ news/ story. asp? file= /2010/6/2/nation/6372112\&sec=nation]

Litman, T. and Rickert, T. (2005). Evaluating public transit accessibility: 'Inclusive Design' performance indicators for public transportation in developing countries. Retrieved 29 February 2012 http://www.sortclearinghouse.infol

Litman, T. (2005) Well Measured: Developing Indicators for Comprehensive and Sustainable Transportation Planning. Victoria Transportation Policy Institute, Victoria, British Columbia, Canada.

Martin V. L., (2004) A New Approach to Sustainable Transport Systems. $13^{\text {th }}$ World Clean Air and Environmental Protection Congress, London.

Ministry of Transport Malaysia Annual Reports (2006), Ministry of Transport Malaysia.

Ministry of Transport Malaysia Annual Reports (2008), Ministry of Transport Malaysia.

Ministry of Transport Malaysia Annual Reports (2010), Ministry of Transport Malaysia.

Ohnishi, K. and Chris, S. (2000). "Labour economics: issues and challenges", pp.13-35 in The Globalization, edited by K. Ohnishi and S. Chris. Kuala Lumpur: IIUM Press.

Pender, L. (1999) Marketing Management for Travel and Tourism, UK, Stanley Thornes Publishers Ltd.

Pizam, A., Neumenn, Y. \& Reichel, A. (1978) Dimensions of Tourists Satisfaction with a Destination, Annals of Tourism Research, 5(2), pp.314-322.

Pizam, A. \& Mansfield, Y. (2000) Consumer Behaviour in Travel and Tourism, New York, The Haworth Hospitality Press.

Rietveld P., Bruinsma FR., van Vuuren, DJ. (2001) Coping with unreliability in public transport chains: A case study for Netherlands, Transportation Research Part A. 
Syahriah Bachok, Mariana Mohamed Osman, Ummi Aqilah Khalid \& Mansor Ibrahim

Commuters' Perceptions on Rail based Public Transport Services: A Case Study of KTM Komuter in Kuala

Lumpur City, Malaysia

Road Transport Department Malaysia, (2011). Car Registration Statistic [Accessed 2 Jan 2012, at http:// portal.jpj.gov.my/index.php?optioncom_content\&view=article\&id $=61 \% 3$ Astatistik-pendaftaranmotokar $\&$ catid $=23 \% 3$ Astatistik-kenderaandan-pemandu\&Itemid118\&lang $=\mathrm{ms}$ ]

Senbil, M., A. Fujiwara, J. Zhang, and D. U. Asri (2005) Development of a choice model for evaluating sustainable urban form. Proceedings of the Eastern Asia Society for Transportation Studies 5: 2164-2178.

Schiffman, L \& Kanuk, L. (1987) Consumer Behaviour, Motivation research, Marketing.

Shwarcz, S. (2003). Public Transportation in Malaysia: 1-24

Swarbrooke, J. \& Horner, S. (2001) Consumer Behaviour in Tourism, Oxford, Reed Educational and Professional Publishing Ltd.

World Bank (1996) Sustainable Transportation: Priorities for Policy Reform. The World Bank, Washington D.C..

International Council for Local Environmental Initiatives (ICLEI) (2001), Sustainable Transportation Options for Protecting the Climate: A Guide for Local Governments, Berkeley.

Tara R., Josias Z., William E., Duane R., Debbie S. and Brian B. (2009)., Developing Sustainable Transportation Performance Measures For Txdot's Strategic Plan: Technical Report, Texas Transportation Institute.

Tran, T. \& Kleiner, B. H. (2005). Managing for excellence in Public transportation. Management Research News 28(11/12): 154-163.

Transportation Research Board, \& Kittelson and Associates, Incorporated. (2003). A Guidebook for Developing a Transit PerformanceMeasurement System. Transit Cooperative Research Program (TCRP) Report 88, Transporation Research Board, Washington.

Transit Cooperative Research Program Report 88 (2003). A Guidebook for developing a transit performance-measurement system. Washington DC.

Utusan Malaysia. (2008) Utusan Malaysia Online. August 25, Retrieved January 15, 2009, www.utusan.com.my

Wen-Ji, H. (2003) A Passenger's Choice Model of Train Service with Elastic Demand. Journal of the Eastern Asia Society for Transportation Studies, 5, 252-264.

World Commission on Environment and Development (Bruntdland Commission), Our Common Future. Oxford University Press, Oxford, England, 1987.

Zaherawati Z., Zaleha H., Mohamed Fajil AB. \& Zuriawati Z. (2010) Service Quality of Malaysian Public Transports: A Case Study in Malaysia, Cross-Cultural Communication, Vol. 6, No. 2: 84-92. 